\title{
A SYSTEMATIC LITERATURE ANALYSIS ON ENTREPRENEURIAL ORIENTATION AND BUSINESS PERFORMANCE
}

\author{
DOI: 10.17261/Pressacademia.2018.955 \\ JBEF- V.7-ISS.3-2018(6)-p.269-287
}

Hewa Kumbalgoda Gamage Sriyani Ranasinghe ${ }^{1}$, Mohd Shukri Abd. Yajid ${ }^{2}$, Ali Khatibi ${ }^{3}$, S. M. Ferdous Azam ${ }^{4}$

${ }^{1}$ Management \& Science University, Shah Alam, Malaysia. hksri@sjp.ac.lk, ORCID: 0000-0002-7205-4783

${ }^{2}$ Management \& Science University, Shah Alam, Malaysia. shukri@msu.edu.my

${ }^{3}$ Management \& Science University, Shah Alam, Malaysia. alik@msu.edu.my

${ }^{4}$ Management \& Science University, Shah Alam, Malaysia. drferdous@msu.edu.my

Date Received: July 14, 2018

Date Accepted: September 9, 2018

To cite this document

Ranasinghe, H. K. G. S., Yajid, M. S. A., Khatibi, A., Azam, S. M. F. (2018). A systematic literature analysis on entrepreneurial orientation and business performance. Journal of Business Economics and Finance (JBEF), V.7(3), p.269-287.

Permemant link to this document:http://doi.org/10.17261/Pressacademia.2018.955

Copyright: Published by PressAcademia and limited licenced re-use rights only.

\section{ABSTRACT}

Purpose- Entrepreneurial Orientation (EO) has received substantial attention in entrepreneurship research in recent years. However, this aspect has not been fully considered in relation to graduate entrepreneurs in the university systems. This article aims to investigate the relationship between Entrepreneurial Orientation and Business Performance.

Methodology- 15 empirical research and 126 articles published in relevant journals were selected through major indexes: ISI, SCOPUS and Google Search. The methodology incorporated theses and articles which showed a relationship with the two constructs from 20002018. This article proposes a conceptual model consisting of some specific dimensions of EO: entrepreneurship desire, innovativeness, proactiveness, risk-taking and networking capability.

Findings- The limited number of research conducted in this area previously does not cover the issues of graduate entrepreneurs and numerous doubts on EO remain unanswered.

Conclusion- The proposed recommendations strongly advocate for future empirical research of this topic, whereby it would add new pragmatic knowledge to the existing.

Keywords: Entrepreneurship, entrepreneurial orientation, business performance, graduate entrepreneur, systematic analysis. JEL Classification: 123, A23

\section{INTRODUCTION}

Measuring Business Performance (BP) through the impact of Entrepreneurial Orientation (EO), in today's economic environment is a critical issue for academic scholars and practicing entrepreneurs. In the recent years numerous disciplines have shown a keen interest in the two main constructs which have been used in many empirical research. EO can be considered as a new tendency to evaluate the performance of a new venture (Kraus, Burtscher, Vallaster \& Angerer, 2018) as well as a continuing study area that takes place in existing organizations throughout the world (Sok, Snell, Lee, \& Sok, 2017). The available characteristics combine and act together to form an environment where entrepreneurial players get the opportunity: I) to grab current markets in some cases while generating new ones in others, II) to capture market share from competitors who are less forceful and innovative, and III) to acquire the customers, assets and also the employees of demure present businesses (Hamel, 2000; Lackeus, 2018). Improving the entrepreneurial business is a prominent factor required for the progress of any country irrespective of the fact that it is developing or developed. Information is generated 
in the present, much more than earlier, through research with regard to the entrepreneurial businesses and improvement of methodologies in social sciences (Kraus, Burtscher, Vallaster \& Angerer, 2018, Memon, Ting, Ramayah, Chuah \& Cheah, 2017). Besides, it is highlighted in entrepreneurship literature that there is a huge gap in some developing countries when compared with the developed countries. (Kumara, 2012).

The present view point of EO can be regarded as the processes accountable for strategic decision making and the method of entrepreneurial activities involved in a business (Omisakin, Nakhid, Littrell, \& Verbitsky, 2016). In the competitive business world, EO is recognized as a strategic practice (Rae \& Ruth, 2013) which allows creative method of entrepreneurial behavior and practice (Beliaeva, 2014). In this article the selected dimensions of EO are entrepreneurship desire, innovativeness, proactiveness, risk-taking and networking capability (Taatila, 2012). Further, it is defined as a precise concept which has an effect on the BP and a notion with considerable contribution to the success of the venture (Mahmood \& Hanafi, 2013).

BP is identified as the most suitable option to evaluate efficiency and effectiveness of the level of business within a given period by using the income, return on sales, customer satisfaction and goals attainment (Afrifa, \& Padachi, 2016). Further, it is considered to fluctuate based on the type of the business and it is understood that mainly due to multidimensional nature, different tools and techniques are used to measure it (Gerba \& Viswanadham, 2016). Construct of BP can be explained in terms of effectiveness, efficiency, relevance and the financial viability too (Arham, 2014). BP is sometimes described as the successful phase of action or collection of the actions or intention by the Small and Medium Enterprises (SMEs) in a country (Raimond, 2016) while it is acknowledged as the best criteria for evaluation and measurement of the efficiency and effectiveness of the SMEs within a given time period. It is stated that especially in Europe, SMEs serve a vital role (Mudalige, Ismail \& Malek, 2016) with nearly 23 million that amounts to $99 \%$ of all running businesses, employing 75 million employees representing more than $80 \%$ of the employment rate in certain sectors (Priyanath \& Premaratne, 2014). Statistics indicate that SME sector of Sri Lanka as a developing country also has a contribution of $80 \%$ of all business categories, to the established businesses (Gamage, 2014). Therefore, SMEs are considered as the back bone of the many economies too (Mudalige, Ismail \& Malek, 2016). Hence, this discussion is very important in the current context, exposing an outstanding alertness for the sustainable growth of most of the countries.

EO supports the use of existing knowledge to move forward to the performance of any businesses run by the SMEs (Weerakoon, 2014). Alongside, different perspectives of theories have been considered by many authors to highlight the relationship between EO and its numerous dimensions (Taatila, 2012) in building up the business environment. However, in the Sri Lankan context only a limited number of studies had been done earlier to examine this important aspect of EO using several dimensions within specific theoretical backgrounds (Kasturiratne, 2012; Ranasinghe, 2008). In spite of the many empirical studies carried out on the subject of EO during the last several decades, still there are research gaps which need to be tackled (Miller 2011; Wales, Gupta, \& Mousa. 2011). This article selected the available literature from 2000 to 2018 for a Systematic Literature Review (SLR) and some vital gaps concerning EO and BP are highlighted based on the relevant literature. It is seen that although EO has numerous dimensions, only a few were applied in many of these studies relating to this field. Out of these Innovativeness, Proactiveness and Risk-taking were prominent EO dimensions, most authors used in their research. (Al-Ansari, 2014; Aloulou \& Fayolle, 2005; Beliaeva, 2014; Bigliardi, 2013; Ejdys, 2016; Hult, Hurley \& Knight, 2004; Karyotakis \& Moustakis, 2016; Kropp \& Zolin, 2005; Lee, Lee \& Pennings, 2001; Morris, Kurato, \& Covin. 2008; Ofem, 2014; Omisakin, Nakhid, Littrel, \& Verbitsky, 2016; Rauch, Wiklund, Lumpkin \& Frese, 2009; Runyan, Droge, \& Swinney, 2008; Wiklund \& Shepherd, 2005; Yang, 2008). Further, it was observed that other popular EO dimensions were Innovativeness, Proactiveness, Risk-taking, Competitive Aggressiveness and Autonomy (Duru, Ehidiamhen \& Chijioke, 2018; Kaunda, 2012; Lumpkin \& Dess, 2006; 2001; Sriprasert, 2013). In addition, it has been found that many EO related studies were conducted with the use of EO dimensions in different combinations (Soininen, 2013; Covin \& Slevin, 2001). Hence, the dimensions of Entrepreneurial Desire and Networking Capability of EO were selected for this study as it was revealed from the literature that these dimensions play a vital role and rarely used in empirical studies (Taatila, 2012) in relation to the graduate entrepreneurs in the university system.

Although, many research had been carried out using innovativeness, Proactiveness and Risk-taking of EO studies in different perspectives for various disciplines, it is noted that in the university system the application is minimal. This study attempts to focus on the gap of these three dimensions along with the above Entrepreneurial Desire and Networking capability in relations to EO for constructing the proposed model. Besides, it is apparent from literature that most studies have been conducted using the common, traditional views (Al-Ansari, 2014; Beliava, 2014; Kaunda, 2012; Lumpkin \& Desks, 2001,2006; Sriprasert, 2013; Taatila, 2012). Hence, it is fitting at this juncture to adopt novel theories, concepts, models and frameworks in innovative methods as highlighted in Entrepreneurship Theory, Learning Theory, and Competency Theory.

Further, it is evident that many relationships and conceptualizations that could be investigated with regard to EO had not been considered due to inadequate awareness, unwillingness to test new concepts due to the fear of unsuitability resulting from cultural, social and environmental issues of some countries (Gamage, 2014; Weerakoon, 2014; Wijesekara, Kumara \& 
Gunawardena, 2014). This situation needs to be conquered enabling sustainable development of the countries and the present study intends to contribute towards this exercise through systematic literature analysis. The systematic literature analysis supported in examining the background related to the questions which were formulated, explaining that at present there is no appropriate EO system or framework in the university system which enables the success of graduate businesses (Wedathanthrige, 2014). Therefore, it is important to examine how the graduate entrepreneurs could overcome contemporary issues in their businesses using the best practices within the EO system (Buckley \& Park, 2014; Fani, 2015). Hence, the conditions under which these dimensions have an impact on EO among the graduate entrepreneurs in USJ and in what ways, are are the questions handled in this article.

Therefore, the aim of this article is twofold and the first is to study the dimensions with respect to EO among the graduate entrepreneurs of the University of Sri Jayewardenepura (USJ) in Sri Lanka. At the outset, theoretical concepts of EO were studied in order to discover the different types of dimensions on the basis of the appropriate theories, approaches, and models to meet this requirement. The second aim is to develop a conceptual framework indicating the association EO bears with the dimensions especially selected for this article, on examining extensive systematic literature analysis on the subject.

\section{LITERATURE REVIEW}

\subsection{Development of Theoretical Review}

It has been stated that the development of entrepreneurial theories can be acknowledged from diverse perspectives (Callaghan \& Venter, 2011). Theories are incorporated to understand the basic concepts which become necessary to have results and actions bearing a clear mind in an advanced method, avoiding repetition without any clarification. Theories can fundamentally have impact at all feasible levels, on influencing a conclusion. It is noted that the various points of view arise as a result of the differences in descriptions due to the theories that need further testing (Amolo \& Migiro, 2014). This section provides a brief explanation on literature in relation to EO giving priority to the selected dimensions relevant to graduate entrepreneurs in the USJ involved in SMEs. The systematic literature review is the style of literature used to prepare the article extracting the enormous knowledge on the existing topic.

\subsection{Theoretical Perspectives of Entrepreneurial Orientation}

The importance of entrepreneurial process in the development of the society is conspicuous (Omisakin, Nakhid, Littrell, \& Verbitsky, 2016) which proceeded to the literature. Different, theories, perspectives and models have been used to express EO for a considerable time period as shown in it. Some of the processes which are relevant to the topic have been reflected in this article to make this attempt complete. Learning Theory, Theory of Planned Behavior (TPB), Contingency Theory, Lumpkin and Dess model, Taatila Model along with Kaunda model supported to the theory development procedure in the article. In order to recognize the behavior representing different dimensions in relation to the graduates' EO environment, this article uses Learning Theory depicting their entrepreneurship experiences, and TPB focusing on entrepreneurial intention. Moreover, Learning Theory expresses that entrepreneurship is a collection of activities that consist of learning, while theory of learning is included in entrepreneurship (Minniti \& Bygrave, 2001). The prominent relative learning styles of business setting concentrates on learning from peer groups, by doing work, responses from customers and suppliers, by experiment, by problem solving, opportunity taking and learning from making mistakes by the learner (Minniti \& Bygrave, 2001).

TBP could be used in the case of new comers who start new ventures, who are expected to practice proactiveness by having intentions showing the behaviour. The attention of many researchers was drawn to EO concerning the attributes of graduates during 1990s(Poon, 2013). Researchers study entrepreneurship to find answers to what, how and why, and generally collect information on EO (Cope, 2011). It is highlighted that in relation to EO, a business can succeed or fail (Kaunda, 2012) depending on the entrepreneurship nature of the individual and the process of EO which is not similar between two individuals. TBP provides the basis for the theoretical approach where EO activity certainly symbolizes the model. It is worthwhile to note that the field of entrepreneurship has generally ignored TPB in their research but this theory has been used to a great extent in many other disciplines for their research as highlighted in the literature.

Besides, the contingency approach expresses as to how a third variable affects the relationship between two variables and it mainly considers the adequate position of entrepreneurship. The behavioral manner suitable for successful implementation of the business at an adept level in different perspectives and the effect of a variety of issues in relation to EO is shown by the Contingency approach. This article is based on the model of Lumpkin and Dess which is interpreted from the above theories, while concentrating on the specific dimensions of EO (Kaunda, 2012). The five dimensions were selected for the present article from Taatila model where the empirical study of the above theory and model is presented. The prime importance of the above dimensions of EO in dealing with entrepreneurial characteristics was shown by many studies (Taatila, 2012) based on the identified gaps of the study. It is of great concern to overcome this awkward situation in view of the sustainable development of the country, which is what this study aims to attain in this exercise. Therefore, it 
would be appropriate that this study need to be examining the relevant theories, concepts, models and frameworks, to investigate on the relationship between EO and BP leading the selected respondents in the above study area of the article in the university system. Hence the following figure 1 given below, presents the EO structure indicating the relationship between EO and its dimensions through systematic literature analysis. (Source: Taatila, 2012).

\subsection{Definitions of Entrepreneurial Orientation}

It is not possible to find a universally accepted definition for entrepreneurship that has received agreement (Carland, Carland, \& Carland, 2015). Entrepreneurship is considered as a mindset which is of great interest to the academic researchers and accountable resource persons in a country such as policymakers, economic institutions universally and it is generally a preferred career path for sustainable developed and developing countries. Intensification of entrepreneurship is considered as important for any business venture that is reaching out to global and changeable environment in the current persevering business setting (Arham, 2014). It is evident that research findings led to discover the main components in relation to EO environment (Lumpkin \& Dess., 2001) indicating that Entrepreneurship could be applied to many areas such as social, economical, cultural, family, education and government sectors which are of interest in the society (Buckley \& Park, 2014).

\subsection{The Structure of the Entrepreneurial Orientation}

Entrepreneurial Desire, Innovativeness, Proactiveness, Risk-taking and Networking Capability are the selected dimensions of this study. The construct of the modified multidimensional model of EO that comprises its dimensions are shown in the figure 1 as follows: (Source: Taatila, 2012).

Figure 1: Modified Multidimensional Structure of EO

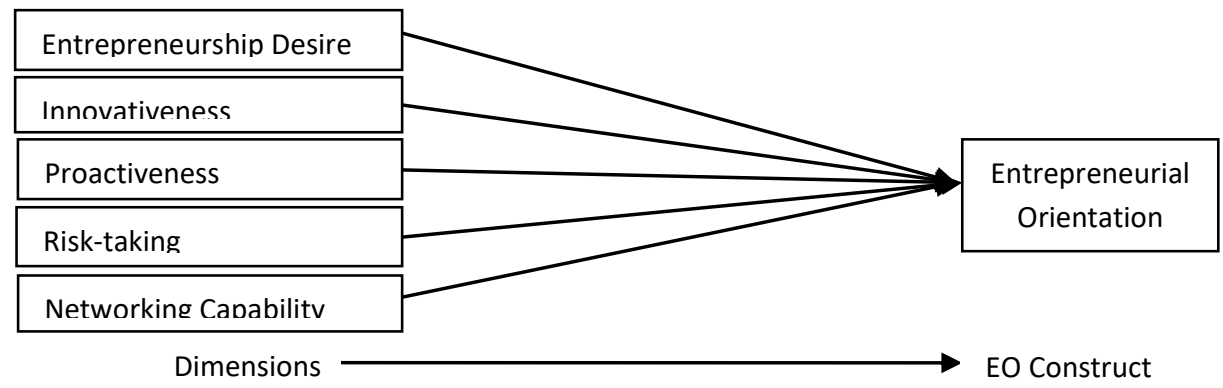

(Source: Taatila, 2012).

The dimensions that contribute to the modified multidimensional model of EO that was created in this study are explained as follows:

\section{Entrepreneurial desire}

The first dimension, entrepreneurial desire is selected as a main driving force behind the successful business environment, as it is considered to be one of the vital dimensions of EO in business (Boohene, Marfo-Yiadom \& Yeboah, 2012). Moreover, it is clear that entrepreneurial desire is controlled by the specific and professional cultures of EO (Mazzarol, Volery, Doss \& Thein, 2000). Therefore an entrepreneur who realizes opportunities and uses them for a profit potential invariably exhibits this (Shane \& Venketaraman, 2000, 2001).

Entrepreneurship desire is regarded as the common denominator which has a powerful force among entrepreneurs. Two kinds of entrepreneurial desires can be identified where the first is the entrepreneur and the second is to achieve something entrepreneurial. Although both may direct to success, the difference is that the former thinks to provide achievement. An empirical study in relation to entrepreneurs and non-entrepreneur graduates titled as impact of entrepreneurship education on intention and desire for venture creation that was carried out in Pakistan with a sample of 160 participants concluded that desire for venture creation is one of the variables that become helpful for entrepreneurial intention (Ilyas, Zahid, \& Rafiq, 2015). 


\section{Innovativeness}

The second dimension of EO is innovativeness which is explained as essential ways through which businesses identify new opportunities and it is also known as a business tendency to get involved in new processes and actions in order to generate new solutions to problems in the business, and considered as a major constituent of EO (Ofem, 2014). It further mentions that innovativeness provides a hint whether a business venture is handling things in improved new ways. Hence, the major role played by innovativeness in business enterprises in the modern society is elaborated and a study was developed on innovation practices as a path to business growth performance. This study which used a sample of 600 Small and medium sized businesses in the emerging UAE market revealed that there is a positive relationship between innovative practices and business growth progress in SMEs (Al-Ansari, 2014). The fact that innovativeness is the ability of the business to ascertain new ideas, new products and new processes fruitfully supports this view (Bigliardi, 2013).

\section{Proactiveness}

The third dimension of EO is proactiveness which can be defined as the activities, the businesses carryout with a view to avoid future problems, requirements and changes that are suitable in detection and judgment of new opportunities (Kropp, Lindsay, \& Shoham, 2008 as cited in Omisakin, Nakhid, Littrel, \& Verbitsky, 2016). The finding of a comparative crosscountry study carried out in Russia and Finland on antecedents and performance outcomes of entrepreneurial orientation, applying samples of 101 in Russia and 109 in Finland confirmed this view (Beliaeva, 2014). The results revealed that international BP is supported by the presence of EO. It was also shown that having an aggressive business environment was an obstacle to entrepreneurial situation and not a facilitator while proactiveness of EO depends on the circumstances and not universal. Furthermore, it is mentioned that a proactive business has a forward-looking nature and new opportunities are associated with proactiveness and innovative actions and regarded as a leader rather than a follower (Lumpkin \& Dess, 2006).

\section{Risk-taking}

The fourth dimension of EO is risk-taking which is explained as the willingness of the businesses to shift from the original business venture into the unknown (Chua, 2014; Perz-Luno et al., 2011 as cited Ejdys, 2016). The increasing insecurity that exists in the internal and external business environments signifies the importance of risk-taking (Karyotakis \& Moustakis, 2016). This view is supported by a research study carried out in Thailand using a sample of 179 entrepreneurs to find the effect of entrepreneurial orientation on the success of community enterprise (Sriprasert, 2013). Innovative, proactive and autonomous entrepreneurs showed a high job satisfaction while risk taking entrepreneurs got more life satisfaction which were the findings of the study.

\section{Networking capability}

The fifth dimension of EO is networking capability. Since a business is not a singular unit of the environment, networking capability is a very powerful dimension of EO and this has been in existence for many years which indicates sharing resources among partners, assisting entry to market and new technologies that a business cannot achieve in isolation. A networking capability refers to the direct ways and means leading to additional competence and resources of the business in order to conquer competitiveness (Taatila, 2012) and it is stated that there is a relationship between networking capability and BP (Rutten \& Boekema, 2007; Jensen \& Greve, 2002). This point of view which states that networking capability can serve the purpose of obtaining and increasing the level of EO and BP, was supported by earlier research studies (Gathungu, Aiko, \& Machuki, 2014). The results of an empirical study that was performed using a sample of 291 small businesses in Sweden on new ventures and small businesses under the title of exploring the effects of network configuration on entrepreneurial orientation and business performance indicated that networking is positively linked to EO and $\mathrm{BP}$ on small businesses.

The five dimensions of EO relevant to this study have been explained above. Next section describes the other main construct of this article which is BP.

\subsection{Theoretical Perspectives of Business Performance}

It is intended to present a review of the past and present research and BP theories as the next step. Since BP shows a multidimensional nature, use of single performance indicators in measuring the BP may provide biased results. Hence it is evident that in earlier studies, diverse instruments were used as an option for BP (Engstrom, \& McKelive, 2016). Small businesses generally measured BP in economic perspectives (Amolo \& Migiro, 2014). Nonetheless, the outcomes of entrepreneurship extend beyond economic feature and it is required to study the social wealth effects or social contribution as a result of entrepreneurship, not only economic wealth creation. Personal satisfaction is also an important reward of entrepreneurship which is obtained through the process of creating value by devoting time, effort and resources and not limited to monetary gains (Kaplan \& Norton, 2010; Rauch, Wiklund, Lumpkin \& Frese, 2009). Another view is that 
the key success factors for businesses were spiritual perspectives but not measured in terms of financial aspects since financial perspective is a comprehensive framework which considers elements that create value such as the way of looking at shareholders, customer perspectives, internal business processes which must be excelled at, learning and growth perspective (Salehia \& Ghorbanib, 2011). There are different approaches in relation to measurement systems of BP. Many specialists and other persons who have a variety of interest observe this concept in different perspectives. It is evident from literature that there are several theoretical frameworks (Goal Approach, System approach) that support assessment of the efficiency on measuring the use of resources in a business. Furthermore, in the Sri Lankan context traditional and new methods have been identified for the measurement of BP (Zsido \& Fenyves, 2015).

\section{Modern business performance measurements approaches}

The changes that happen in competitive environment and plans of current businesses cannot be revealed by traditional performance measures which makes it appropriate to use application methods differently (Zsido \& Fenyves, 2015).

An individual who is in a position to manipulate actions leading to accomplishment of organizational objectives or a person who is a part of it, can be identified as a stake holder. In the mid 1980s it was proved by theories and scientific investigations that sustainable accomplishment and continued existence of businesses cannot be attained only by concentrating on the shareholder value. It was made clear that there exists several stakeholders in businesses who make it indispensable to assign their worth as well. The social changes that determine the image of the business venture and other social views that surfaced are associated with the stakeholder theory to a greater extent. Different business ventures use numerous methods of measurements in evaluation of BP and the selection depends on the type of activities of the business (Zsido \& Fenyves, 2015)

\section{Measurement of business performance}

The multidimensional nature of BP makes it difficult to find one model to measure BP of SMEs individually and diverse tools have been used to measure it based on the purpose of the business (Gerba \& Viswanadham, 2016). It is evident that many empirical research conducted on BP concept have been dealt with the point of view of investigating the consequences of EO. All these empirical research are categorized into specific areas such as present discussion fields, application of theory to research and classification by countries where research were conducted (Beliaeva, 2014).

The results of an empirical study carried out on the financial literacy and business performance in informal economy businesses in Ecuador using a sample of 750 micro enterprises resulted in showing that both financial literacy and role models are very important in envisaging BP for some but not all (Engstrom \& McKelvie, 2016). Another study done in the USA on Entrepreneurial Orientation, Learning Orientation and Firms Performance with a sample of 213 medium to large businesses in UK indicated that learning orientation has a mediating effect on the relationship between EO and BP. Hence these findings highlight that in order to maximize the influence of EO on BP, it is necessary to have learning orientation to successful progress in a changing economy (Wang, 2008). A study carried out in Malaysia using a sample of 284 has proved that produce innovation significantly influenced BP where the effect of the product was stronger than that of the services. Hence innovativeness is identified as an important dimension in the present entrepreneurial activities for SMEs and policy makers (Rasli, Khan, Malekifar \& Jabeen, 2013).

Although performance is a major consideration in all areas and processes, it is convenient to determine the performance of some activities while it is not so simple in others (Zsido \& Fenyves, 2015). Indicators such as effectiveness, efficiency, relevance and the financial viability (Lusthaus, Anderson, Carden \& Montalvan, 2014; Arham, 2014) are used in many research to define BP. A study on exploratory research carried out using a sample of 178 SMEs, on relationship between EO dimensions and BP along with growth of fast and slow growing small and medium enterprises in Bosnia and Herzegovina revealed that in large businesses, EO dimensions are more visible than in small businesses. Further, it has been found that BP of large and small businesses indicates little and moderate significant relationship with EO dimensions (Palalic \& Busatlic, 2015). Furthermore, it is also stated that any variation in sales growth and employee growth were associated with changes of innovation, risk taking and the age of the business. Another factor highlighted was that SMEs are required to be innovative, proactive and taking risks to effect significant business growth and expand faster. In addition it is also important to note that business age of the SME is responsible for having an opportunity to accomplish enhanced BP. A similar study done in Nigeria titled as Knowledge management, entrepreneurial orientation and business performance concerning the role of business culture with a sample of 640 entrepreneurs in SMEs, found that knowledge management and EO has a significant and positive relationship with BP. Further it is highlighted that there is a requirement for continuous improvement of knowledge management and EO practices to enhance BP by investing resources and time (Aliyu, Rogo, \& Mahmood, 2015). 


\subsection{Definitions of Business Performance}

When examining any definition of BP it appears to be nonexistent unless there is something to be benchmarked. Therefore, finding a universally acceptable general definition for BP is not an easy task (Gavrea, llies \& Stegerean, 2011). Although the dimension of BP is frequently used in the intellectual documentation, it is complicated to define BP since it has many explanations (Gavrea, llies \& Stegerean, 2011). Further objectives of the organization and policies are often used to interpret BP. National and international literature specifies that many researchers define BP in terms of efficiency, effectiveness and economic efficiency (Bocskei \& Fekete, 2012). It is worthwhile to note that items such as value creating, quality, productivity, innovation and changing ability serve a supplementary task. Some researchers have explained BP as the accomplishment of a mission that could be measured in comparison with a predetermined known value of precision, totality, expenditure, and the rate of achieving the financial and non financial results of the venture (Hudson, Smart \& Bourne, 2001).

\subsection{Relationship of Entrepreneurial Orientation and Business Performance}

Literature enumerates that the impact of EO on BP is illustrated by using different types of perspectives. The relationship between EO and BP is presented in the figure 2 as follows: (Source: Journal of Small Business \& Entrepreneurship, 2015).

Figure 2: The relationship between Entrepreneurial Orientation and Business Performance

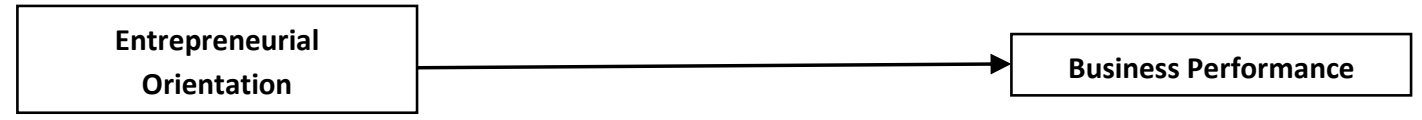

(Source: Journal of Small Business \& Entrepreneurship, 2015).

Research indicates that BP is associated with EO of the business to a greater extent. The attention of numerous scholars, was focused on the relationship between EO and BP (Schepers, Voordeckers, Steijvers \& Laveren, 2014) arguing that an enhanced level of EO results in increased performance (Al-Nuiami, Idris, Al-Ferokh \& Hussein, 2014; Schepers, Voordeckers, Steijvers \& Laveren, 2014; Van Doorn, Van Jansen \& Van den Bosch, 2013; Vij \& Bedi, 2012). The view that a positive relationship exists between EO and BP is supported by many researchers (Alarape, 2013; Laukkanen, Nagy, Hirvonen, Reijonen \& Pasanen, 2013; Wiklund \& Shepherd, 2005). Using a sample of 500 SMEs, an empirical study carried out in South Africa titled as Entrepreneurial orientation: A case of Gauteng province revealed that EO can be considered as having a high significant relationship with BP (Radipere, 2015). Another study conducted using 209 big family businesses in Malaysia, showed that owners displayed risk-taking. It was also found that among the big family businesses innovativeness was common (Arham, 2014). A similar research study conducted with 599 small businesses in US indicated that EO has a positive relationship with BP and marketing competencies. Further, the study performed in Portugal using 168 small businesses, found that the businesses proved active in using their innovativeness, risk-taking and proactiveness (Azevedo, 2008). Moreover, a study conducted with 181 big businesses in the US revealed that EO is positively related to BP while EO plays a major role in business growth (Hult, Hurley \& Knight, 2004). Based on the above discussion the present study predicts the significant impact of EO on BP. This relationship between EO and BP is the main theme in this study. The relationship between EO and BP is considered to have multidimensional perspectives (Kaunda, 2012) when considering the aggressive situations dealt by businesses in the present context of global economy. Dimension of EO and its impact on the BP is presented in the figure 2 (Source: Omisakin, Nakhid, Littrell, \& Verbitsky, 2016; Radipere, 2015; Kaunda, 2012).

Figure 3: Impact of Entrepreneurial Orientation Dimensions on Business Performance

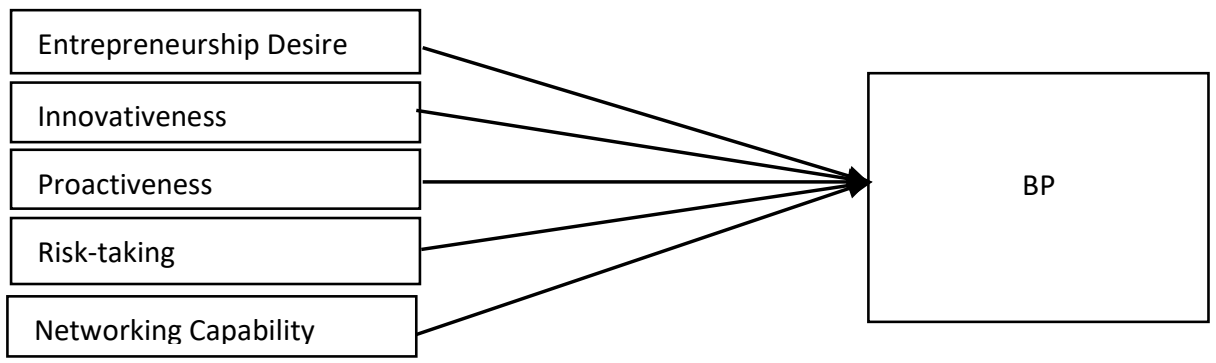

(Source: Omisakin, Nakhid, Littrell, \& Verbitsky, 2016; Radipere, 2015; Kaunda, 2012) 
It is also argued that EO cannot be considered as correspondently suitable in all circumstances as resulted by some practical and theoretical views. By having more research with redefined dimensions, the basic procedures of entrepreneurial actions and multidimensional type of EO would enhance the awareness of EO and its relationship with BP. Hence major attention has been given to the relationship between EO and BP with due consideration to the favorable perspectives of entrepreneurial actions that have on business development and performance. EO is regarded as an essential element for businesses with the objective of competing in aggressive business circumstances. On the other hand, there are points of view that suggest positive association of the EO on BP depend on the situation and could change autonomously within a given business framework.

Therefore, BP indicates an association with entrepreneurship desire, innovativeness, proactiveness, risk-taking and networking capability of the business, which are identified as EO dimensions for this study. There has been a greater discussion on this concept (Lumpkin \& Dess, 2006) and empirical point of view (Omisakin, Nakhid, Littrell, \& Verbitsky, 2016; Radipere, 2015) with regard to the relationship between EO and BP. Although many queries remain unsolved (Moreno \& Cassilas, 2008), EO is identified as a concept that can be used to measure BP, as some investigations indicate improved BP in businesses that practice EO (Brown, Davidsson, \& Wiklund, 2001). A study conducted on Nepalese handicraft enterprises, to examine the relationship between EO and BP of handicraft industry using a sample of 196, indicated that autonomy, risk-taking, pro-activeness and competitive aggressiveness were positively correlated with business performance but innovativeness had no association with it (Gautam, 2016).

Another empirical research carried out to study entrepreneurial orientation, uncertainty avoidance and firm performance which is an analysis of 478 Thai and Vietnamese SMEs, proved that Thai SMEs are more innovative and proactive than the Vietnamese ventures, while Vietnamese SMEs prone to increased risk-taking. At the same time Thai SMEs indicated to have higher perceived business growth, job creation and net profit than Vietnamese SMEs (Swierczek \& Ha, 2003). Using a sample of 94 business units a research performed in the USA on Linking two dimensions of entrepreneurial orientation to firm performance to assess the moderating role of environment and industry life cycle, found that two of the dimensions of EO have a tendency to vary independently of each other, and also their effect on performance depend on moderating variables. Hence it is stated that future research could benefit by taking into account the independence of other dimensions of EO and considering EO from the perspective of multidimensional view in order to investigate these complex issues (Lumpkin \& Dess 2001). It is interesting to note that the leadership behavior and EO play a major role as predictors for the progress of SMEs which was the outcome of a study on the relationship between leadership behaviour, entrepreneurial orientation and organizational performance done using 384 Malaysian small and medium enterprise (Arham, 2014) An empirical research on proposing and validating a five-dimensional scale for measuring entrepreneurial orientation conducted in China with a sample of 408, found that EO as a second-order reflective model on which many researchers agreed upon (Zhang, Zhao \& LeCun, 2015).

A comparative analysis of corporate entrepreneurial orientation between selected firms in the Netherlands and the USA was done which revealed noteworthy disparities between the Netherlands firms and the US counterparts in entrepreneurial orientation. These comparative differences were observed among three key dimensions of strategic management as they relate to corporate entrepreneurship. A relationship between corporate entrepreneurship and three measures of firm performance was also observed and the important finding was that culture could play a facilitating role on corporate entrepreneurship and adaptable organizational practices (Kemelgor, 2002). With a sample of 764 a study was performed in the USA to investigate the role of entrepreneurship in building cultural competitiveness in different organizational types which found that specifically, large and young organizations indicate a direct relationship between powerful performance and entrepreneurship while other organizational types show an indirect effect of entrepreneurship on performance. Further it is enumerated that large and old organizations carry out efficiently by paying attention to organizational learning and on the other hand small and old organizations get advantage from a market orientation while small and young organizations become successful by having a unbiased approach on cultural competitiveness (Hult, Snow \& Kandemir, 2003)

Another addition to the prevailing literature was a study carried out on entrepreneurial orientation and perceived financial performance with an aim to find out whether environment always moderate EO performance relation in Turkey, with a sample of 107 SMES, which depicted that although a relationship between EO and perceived financial performance of the businesses exists, it is not effective. Therefore, the nature of the relationship between EO and performance along with the moderating role of environment is queried (Kurtulmuşa \& Warnerb, 2015). An empirical research study done in Austria on obtaining information from 266 businesses to investigate the impact of entrepreneurial orientation on firm performance which is a comparative study of Finnish and German SMEs, highlighted that the SMEs of both countries demonstrate increased levels of all EO dimensions. Further it showed that, the Finnish SMEs display enhanced intensity of innovativeness, proactiveness and EO when compared with German equivalents, while no considerable disparity was shown in the levels of risk-taking. In addition, innovativeness appeared to be the construct that had the highest contribution to firm performance in the SMEs of both countries and it is fascinating to note that the impact of 
innovativeness by itself was greater than that of the combined EO concept. Lastly, there was no major difference between the strength of the impact on performance with any of the existing dimensions between the Finnish and German firms (Piirala, 2012). Another vital addition to the existing knowledge is the findings of a replication study conducted on entrepreneurial orientation and business performance, using 266 units as the sample in Austria. Although a positive relationship indicated between EO and business performance according to Wiklund and Shepherd's study (2005) this replication study showed a negative link not statistically significant between EO and business performance in certain configurations (Frank, Kessler \& Fink, 2010). A research study done in order to find out the relationships of entrepreneurial orientation and small business orientation (SBO) have on firm performance in USA with a sample of 267 revealed that the links of EO and SBO to performance are not similar in these groups as EO clearly connects to performance among the younger group while SBO is responsible in the case of the older group (Runyan, Droge, \& Swinney, 2008).

Another quantitative study performed in the Netherlands using 164 units as sample to investigate the link between entrepreneurial orientation and the business performance of SMEs indicated that proactiveness of firms have a positive contribution to SME performance within the economic crisis. It was also revealed that SMEs with innovativeness, carry out in an improved manner in unstable environments if risk is avoided (Kraus, Rigtering, Hughes, \& Hosman, 2012).

Using 149 manufacturing companies an empirical research was conducted to analyze entrepreneurial orientation of SMEs, product innovativeness, and performance in Greece where two opposite groups were recognized as the active entrepreneurs and the passive entrepreneurs. It also highlighted that product innovators in these groups share the responsibility of reducing customers' load such as time, effort and purchase risk, in implementing new products. Nevertheless, the entrepreneurial attitude of active entrepreneurs mainly reflect in new products demonstrating a higher uniqueness, as compared with passive entrepreneurs which is responsible for product performance (Avlonitis, Salavou, 2007).

Further, dimensions of EO has recently been recognized as the most important attributes for measuring the growth of a business and profitability while at the same time research has shown that high growth of business is associated with EO (Zainol \& Ayadurai, 2011). Entrepreneurship desire, innovativeness, pro-activeness, risk-taking and networking capability of the business have the possibility of adopting EO.

\section{Entrepreneurial desire and business performance}

The desire for independence in relation to entrepreneurship is generally considered as an important inspiration for entrepreneurial business (Hanafiah, Yousaf \& Hashim, 2016). A study performed using entrepreneurs in Venezuela on the problems they face, and success factors of business, denoted that their desires to become one's own boss in a business and to increase the income of a business are vital motivators and there is a relationship between them (Zimmerman \& Chu, 2013). Further findings of another research exposed that entrepreneurship capacity of university students should be made strong through developing entrepreneurship education, allowing more entrepreneurship opportunities and enhancing the entrepreneurship desire by a relevant financing system to persuade graduates to begin new ventures and become entrepreneurs (Quinlan, 2011). It was also a vital finding that although all the students consider intention of recognition as important, individual factors for the desire of becoming entrepreneurs are diverse and it is required to promote more graduates to initiate and manage businesses (Friedman, Aziz, Keles \& Sayfullin, 2012) which was the outcome of a research study carried out in Georgia, Kyrgyzstan and USA, with a sample of 305 undergraduate business students.

Measuring entrepreneurial orientation in university students was the objective of a study performed in Finland and significant differences were indicated between academic programs in their entrepreneurial desire but no variations were observed in the sub variables of EO. However students who were already entrepreneurs obtained high statistical significance in all of the five dimensions of EO (Taatila, 2012).

\section{Innovativeness and business performance}

Innovativeness is regarded as the pathway to success for any activity including newly started small businesses. The small businesses generally depend on traditional methods for products, services and distribution, if these lack innovativeness (Lee, Lee \& Pennings, 2001). Hence, innovativeness is acknowledged as a characteristic which provides a positive affiliation to BP (Hult, Hurley \& Knight, 2004; Kreiser, Marino \& Weaver, 2002; Avlonitis \& Salavou, 2007). It was pointed out by a study done in Sri Lanka that innovativeness indicates a positive, significant relationship with BP (Fairoz, 2010). Another important revelation was that innovativeness is the most significant dimension of EO which indicates a consequence for BP which was the result of a study conducted in Australia among four different industries (Coulthard, 2007). Further, another empirical finding was that there is a positive relationship between innovativeness and product performance (Baba \& Elumalai, 2011).

Innovativeness: Its antecedents and impact on business performance was the title of a research carried out in USA using 181 businesses where the proposed model consisting of market orientation, entrepreneurial orientation and learning 
orientation were taken as key antecedents to innovativeness along with testing the direct relationship between innovativeness and business performance in general and in the situation of different market turbulence. The outcome confirmed the validity of the model and highlighted several insights on the role of market turbulence in the proposed relationships (Hult, Hurley \& Knight, 2004).

A research study carried out in Sri Lanka using 57 SMEs to investigate entrepreneurship orientation, business performance as an appraisal of small and medium scale enterprises with reference to Hambanthota District found that innovativeness and proactiveness have a clear effect on business performance. Further, innovativeness was regarded as a vital construct in measuring business performance which increased as the number of employees increased (Gamage, 2014).

Another similar study done in Malaysia with 284 SMEs to analyse the impact of innovation on the performance of small and medium manufacturing enterprises depicted that BP has a significant connection with produce innovation when the effect of the product was stronger than the services. It was also highlighted that innovation is a very important factor for SMEs and policy makers in the present entrepreneurial activities (Rosli \& Sidek, 2013).

\section{Proactiveness and business performance}

The proactiveness dimension can also be considered as of utmost importance for the success of small business (Arham, 2014). A study carried out in Sri Lanka on SMEs revealed that proactiveness bears a positive affiliation on the overall BP (Fairoz, 2010). This fact was further confirmed by an empirical study performed in the Netherlads with 94 businesses which divulged that proactiveness has a strong relationship with BP (Kraus, Burtscher, Vallaster \& Angerer, 2018). A similar study conducted in Malaysia using 210 SMEs supported this finding that proactiveness and BP has a significant relationship (Awang et al., 2009).

A research study performed in South Africa with 103 businesses to investigate entrepreneurial orientation, age of owner and small business performance in Johannesburg, South Africa, showed that in comparison to other dimensions the proactiveness of the entrepreneur has an effect on EO, while risk taking and innovativeness did not indicate a major link on the relationship between EO and BP. It was also found that the age has an negative relationship with EO and BP (Kaunda, 2012).

Another research which analyzed the effects of entrepreneurial orientation on business performance in South Africa with a sample of 466, revealed that proactiveness, innovativeness and risk taking have positive effects on small business performance. It was also clear that in developed businesses, possessing greater financial resources, EO helps to overcome environmental and resource limitations. The results of a study done in USA with 292 units to analyze entrepreneurial orientation, collaborative networks and nonprofit performance, indicated that nonprofit organizations that have limited social resources get more advantage from EO. When innovativeness, risk taking and proactiveness are operating at the same time, businesses with smaller and high homogeneous collaboration, get benefitted over opposite counterparts. Further EO did not indicate any clear relationship with collaborative network size or tie heterogeneity (Ofem, 2014).

\section{Risk-taking and business performance}

Taking actions that would result in uncertainty and heavy borrowings are recognized as risk-taking (Rauch, Wiklund, Lumpkin \& Frese, 2009). Using 236 family businesses, a study was conducted in UK and results denoted that a significant relationship was observed between risk-taking and entrepreneurial business performance (Wang \& Poutziouris, 2010). Furthermore, two different studies carried out in Taiwan (Yang, 2008) and Sri Lanka (Fairoz, 2010) also revealed a significant relationship between risk-taking and BP. It is interesting to note that the recent findings of a study launched in the Netherlands using 164 businesses, pointed out that there is no direct relationship between risk-taking and financial performance in businesses (Kraus, Burtscher, Vallaster \& Angerer, 2018). In contrast to this, the results of another set of studies indicated that risk-taking has a positive relationship on BP, only up to a limit and beyond that increase of risk-taking resulted a decline on BP. The diverse effects of this dimension are confirmed by a study done in Malaysia which revealed that risk-taking indicated a negative connection with objective measure of performance of the business (Awang et al., 2009).

EO in small and medium-sized enterprises during economic crisis was analyzed in Finland with a sample of 193 and it was found that EO shows a positive relationship on the growth of a business over a long period of time. Further, EO does not have any link to the profitability of the business. The contradictory role of risk taking and innovativeness, proactiveness was also surfaced. Risk taking was found to have a negative relationship on profitability and growth (Soininen, 2013).

A study carried out in Sri Lanka with a sample of 109 businesses to investigate Entrepreneurial competencies and entrepreneurial orientation of tea manufacturing firms revealed that background characteristics of owner/managers indicate a direct effect on entrepreneurial competencies. EO showed a direct positive link with entrepreneurs' strategic 
and commitment competencies while innovativeness was also shown to be greatly influenced by owner/managers competencies but risk taking nature was minimum affected by competencies (Wickramaratne, Kiminami \& Yagi, 2014).

\section{Networking capability and business performance}

Literature clarifies that businesses linked by networks have indicated an improved BP (Baum, Locke, \& Smith, 2001). Networking is important due to the fact that the entrepreneurs generally depend on the information, raw materials, technology and new knowledge in advancing their businesses on a regular basis in order to get recognition from the society. Consequently, it is evident that many researchers acknowledged the fact that networking has numerous benefits including enhance of business success. Literature designates that the endurance of a business has a positive relationship with networking (Mulatu, 2014).It has also been clearly enumerated that having network capability with financial institutes and businesses, maintaining the quality of the connections with the network, shows a significant positive relationship with BP (Mulatu, 2014).

Further evidence for the positive relationship networking has with BP is submitted by a study done with a sample of 227 businesses (Ge, Hirsch \& Dong, 2009) in China. Another example that supports this point of view is provided by an empirical study which resulted that electronic social network has a significant influence on BP. In agreement another research disclosed that in the case of new ventures, networking show a positive relationship with financial benefits and growth of these businesses (Hite \& Hesterly, 2001).

Further, literature explains that Uses and Gratification theory offer a suitable framework giving reasons for entrepreneurs to join a relevant network to obtain benefits of the business. Among many empirical research that are in agreement with this view, is another study carried out in Malaysia using 150 SMEs that proved networking is positively related to BP and greater attention is given in the literature for business networking along with knowledge and information sharing which enhances BP (Harvie, 2010).

A study carried out in USA with 70 SMEs to study networking strategy of boards with correlates, performance effects, and implications for small and medium-sized enterprises, supported the view that firms with a networking strategy achieve better performance with higher return on assets (ROA) and higher return on expenditure (ROE) when compared with those that did not actively participate in networks (George, Wood \& Khan 2001).

An empirical research conducted on entrepreneurial orientation, managerial networking, and new venture performance in China and USA with a sample of 300 , interpreted that political networking has a negative moderating effect on the positive relationship between EO and new venture performance. Further it was revealed that financial networking shows an reverted U-shaped link, while business networking has a positive effect. The findings add to the existing knowledge of the impact of managerial networking on the progress assumption of EO in new businesses, and also advocate support on the use of EO and different types of managerial networking in new ventures for enhanced progress in shifting economy of China. (Su, Xie \& Wang, 2013).

\section{DATA AND METHODOLOGY}

Scientists generally accept that online information is resourceful and give leads to many data bases that allow widespread assessment of specific fields within the academic and subject environments (Dahlander \& Gann 2010). However among these high quality publications found in databases, only few articles could be located on the subject of EO on ISI data base. Therefore, another search was made using the same key words on SCOPUS database for appropriate literature. Further, Google Scholar and few other data bases were explored in order to obtain information in relation to EO. Subsequently, after scrupulous examination of around hundred and twenty six articles, fifteen thesis studies and seven books from different data bases were selected for gathering information with utmost care for this specific article.

\section{Proposed Conceptual Model}

The proposed conceptual model applicable to the research question specified in this article, was developed after meticulous consideration of the selected dimensions and relationships highlighted through the literature review. The background of Entrepreneurship Theory, Learning Theory, TPB, Contingency Theory, the models of Kaunda, Tatila along with Lumpkin and Dess, in respect of EO dimensions that relate to the graduate entrepreneurs were given priority in developing the proposed conceptual framework for this article. Hence the following figure 4, demonstrates the proposed model displaying the relationship between EO, its dimensions and BP through systematic literature analysis. 
Figure 4: Conceptual Framework

Independent Variable

\begin{tabular}{|l|l|}
\hline $\begin{array}{l}\text { Entrepreneurial } \\
\text { Orientation }\end{array}$ \\
\hline Entrepreneurship desire \\
\hline Innovativeness \\
\hline Proactiveness \\
\hline Risk-taking \\
\hline Networking capability \\
\hline
\end{tabular}

Dependent Variable

Business

Performance

Finance

Non Finance

Figure 4 shows the relationship between EO and BP as well as the link between the specific selected dimensions of EO and BP. This proposed model indicates the collective viewpoints based on the systematic literature analysis for this study.

\section{FINDINGS AND DISCUSSIONS}

The primary objective of this article is to describe, analyze and synthesize the information sorted out in relation to EO, with a view to propose a conceptual model focusing on the relationship between EO, its dimensions and BP. This was fulfilled after a scrupulous literature review, in order to have a link to the upcoming Sri Lankan graduate entrepreneurs. It was done with the intension of the contemporary requirement to examine entrepreneurial capacities and mindset which provide the graduates with creative thinking, efficient problem solving, communicating, networking with each other and managing the work which are the applicable tools (Ernest, Matthew \& Samuel, 2015). It is understood that there is only few empirical research in the field of business enterprises which examines the concept of EO among SMEs, especially in developing economies (Haider, Asad \& Fatima, 2017). Although many empirical studies have proved the positive link between EO and performance (Tang, Tang, Marino, Zhang \& Li 2008; Rauch, Wiklund, Lumpkin \& Frese 2009; Madsen, 2007; Stam \& Elfring, 2008b) there still remains the lack of generally accepted standard performance measures in relation to small businesses (Akinleye, 2016). By careful examination of the related literature, five major dimensions of EO were selected as important in relation to the businesses of the graduate entrepreneurs. In the contemporary situation, it is essential that any research which relates to the university system, need to focus on the selected dimensions rather than other factors, as found from the literature analysis and have a vital contribution to the national economy.

When considering the innovativeness, a study conducted in Portugal with a sample of 42 businesses demonstrated that EO, especially innovativeness enhances export performance in the SMEs concerned (Rua \& Franca, 2016). The findings of a study done in Pakistan highlighted the importance of EO construct empirically in relation to BP of manufacturing sector SMEs in Punjab. It was revealed that if the manufacture sector SMEs could increase their efforts on innovation, performance improves and similarly, if they try to be pro-active to market changes their performance is sustainable by maintaining their position in the market. Further the risk taking factor was shown to be vital for the growth and performance of SMEs in the manufacturing sector (Haider, Asad \& Fatima, 2017). Another interesting exposure of this study was that when the SMEs spend resources on innovation they could face risk which appears to be helpful for the survival and growth of the business. A conclusion arrived on conducting an empirical research on EO level of SMEs in Mexico with a sample of 318 businesses was that risk-taking has a positive effect in the level of EO adopted and implemented (Maldonado-Guzman, \& Castro, 2016). After a study carried out in relation to social network sizes and risk disposition entitled social networks and entrepreneurial orientation among students in Nigerian Universities using a sample of 94 students, it was recommended that African student entrepreneurs' relationship of networking having a particular focus should be promoted as it serves as an gathering point (Amodu \& Ama, 2016). Although EO studies have been conducted in various business settings and environments it is evident that there exist a scarcity of studies conducted in the Asian countries such as Sri Lanka when compared with the rest of the world. (Wijesekara, Kumara \& Gunawardana, 2014; Priyanath \& Prematatne, 2014; Wedathanthrige, 2014; Nath, 2013; Kasturiratne, 2012).

Therefore, with a view to fill the gap due to lack of research, this article tries to bring up a range of specific dimensions namely, entrepreneurship desire, innovativeness, proactiveness, risk taking and networking capability, implying a conceptual model which promotes phenomenal development of this important topic. This model shows the likelihood of five selected dimensions having an impact on BP. In general, it is assumed that this article would attract the attention of various stakeholders in the field of entrepreneurship as a potential study area. It is highly recommended that the proposed 
model could be used as a device to improve the businesses of the graduate entrepreneurs and encourage them to be outstanding business performers. All these dimensions in the developed model have been clarified and exist in entrepreneurship literature, but the model is yet to be empirically tested. Therefore, this article plans to bridge these identified gaps of EO which represents an area that has little previous research. As a result, this article will help to determine whether EO allows individuals to be strong in their minds with intentions towards entrepreneurship in a positive way. Hence, the conceptual model put forward in this article, will direct scholars on a new path for future studies and investigate to reveal whether these dimensions have a connection related to EO for the upcoming graduate entrepreneurs in the Sri Lankan context.

\section{CONCLUSION}

The conceptual model that is proposed, can be considered as critical for studies to be carried out in the field of entrepreneurship and the suggested constructs should be empirically tested to verify the theoretical assumptions demonstrated in this article. In order to assess the EO, attention was focused on the theories and models along with the previous work of this field. This modified version is made up of the five dimensions of EO model that includes entrepreneurship desire, innovativeness, proactiveness, risk taking and networking capability (Taatila, 2012) all of which have an association with BP as deemed in this article. These major components are considered with the aim of focusing on the future exploration of new research. Entrepreneurial desire is the most frequently used dimension which is considered to have a very strong influence on the business. To be a qualified entrepreneur and act upon it, are the difficult tasks, the business owners usually face. Further, it is their wish to accomplish something entrepreneurial, when doing the businesses. Potential entrepreneurs who have an orientation for growth are likely to be influenced by desire to a great extent, as a business needs much higher commitment and little time for work satisfaction (Judge \& Douglas, 2013). In the recent times the concept of desire has received more attention in entrepreneurship literature. It is clear by the statement "if anything remains constant throughout the journey of entrepreneurship, it is the desire" (McMullen \& Dimov, 2013). Therefore it is notable that in the absence of entrepreneurial desire any investigations on the concept of EO would be incomplete.

The next component, innovativeness is considered as the path of success to any process including new small businesses which has been used as a measure in many empirical studies (Hove \& Goliath, 2016; Kraus, Burtscher, Vallaster \& angerer, 2018; Belgacem,2015; Duru, Ehidiamhen1 \& Chijioke, 2018). It is also one of the key components in the three dimensional model. Since innovativeness is recognized as an essential attribute it is included in unidimensional as well as multidimensional models of EO. It is evident that in today's dynamic business environment with constant rapid changes, effecting appropriate innovations could serve as an important method for achieving competitive advantage which is the main reason for selection. In order to measure the different types of innovation, like form and the degree as well as the heterogeneity of procedures, practices and levels of engagement of businesses, a number of scales are used in empirical research (Belgacem, 2015). It shows the importance of this vital factor in the business which is classified into technological innovativeness, product-market innovativeness and administrative innovativeness (Lumpkin \& Dess, 2006) and lack of it in assessing any of these areas could result in negativity in future research implications. The third constituent of this conceptual model is proactiveness which is also a component considered under three dimensional model. The importance of proactiveness which indicates forward-looking nature of taking initial action in anticipation of future requirements in the existing or emerging markets to create an advantage over competitors (Wiklund \& Shepherd 2005) is shown by using it in many empirical studies (Hove \& Goliath, 2016; Kraus, Burtscher, Vallaster \& angerer, 2018; Belgacem, 2015; Duru, Ehidiamhen1 \& Chijioke, 2018)

The fourth component which is risk taking is the last component of the three dimensional model and used in numerous studies (Zahra \& Garvis 2000; Kemelgor 2002; 2006, Hove \& Goliath, 2016; Kraus, Burtscher, Vallaster \& angerer, 2018; Belgacem,2015; Duru1, Ehidiamhen1 \& Chijioke, 2018). Generally the moderated and calculated risk-taking is focused rather than intense and uncontrolled risk-taking (Morris, Kurato, \& Covin. 2008) but it is of importance to note that having the risk-taking dimension in assessments provides information on the firm orientation towards the assimilation of uncertainty in contrast to enormous fear of it (Kraus, Burtscher, Vallaster \& angerer, 2018). Hence, it is believed that risktaking actions within a business, can be considered as an aspiration to be the leader in trying to creatively meet the demand in a rising market and indicates a high level of EO (Frank, Kessler, \& Fink, 2010). The final component is networking capability which has been used to measure EO in a few empirical research. (Taatila, 2012; Rutten \& Boekema, 2007; Jensen \& Greve, 2002). It is evident that use of networks for SMEs has been increasing in the recent past and it is regarded as an element which shows a relationship in the growth of entrepreneurial processes. The importance of networks in the survival and success of individual firms has been an area that has received very little research attention. Previous research indicates insufficiency of networking capability of a business venture can create a possible difficulty to grow while association between networking capability and BP has not been fully expressed but need to be demonstrated (Mu \& Di Benedetto, 2012). Hence it is worthwhile to assess the networking capabilities of the graduate entrepreneurs and its effect on EO. 
It is universally accepted that in the present economy, SMEs are the driving force of the economic growth of a country (Weimei \& Fenge, 2012). The importance of entrepreneurship has been recognized by many countries and the governments are focusing on promoting small businesses which involve in job creation and income generation, as a solution to unemployment (Sunter, 2000). However, for the new ventures to be successful it is required that these businesses are entrepreneurially oriented (Hove \& Goliath, 2016). On examination of related articles from 2000 to 2018, the importance of studying the dimension of EO for enhanced BP was exposed. Hence, this article proposed the conceptual framework consisting of the above five dimensions that are considered as important among many others that come under EO. Therefore the overall picture of this article is to implement future research based on this model with a view to add new knowledge to the existing literature making the valuable thoughts for novel research world.

\section{REFERENCES}

Afrifa, G. A., Padachi, K. (2016). Working capital level influence on SME profitability. Journal of Small Business and Enterprise Development, 23(1), 44-63. http://doi.org/10.1108/JSBED-01-2014-0014.

Akinleye, D. B. (2016). Impact of entrepreneurship orientation and entrepreneurial management on firm growth: evidence from Nigeria manufacturing industry. Proceedings of the iSTEAMS Multidisciplinary Cross-Border Conference. Ghana: University of Professional Studies, Accra Ghana.

Al-Ansari, Y. D. Y. (2014). Innovation practices as a path to business growth performance: a study of small and medium sized firms in the emerging UAE market (PhD dissertation). Southern Cross University, Lismore, NSW.

Alarape, A. A. (2013). Entrepreneurial orientation and the growth performance of small and medium enterprises in Southwestern Nigeria. Journal of Small Business \& Entrepreneurship, 26(6), 553-577. https://doi.org/10.1080/08276331.2014.892308.

Aliyu, M. S., Rogo, H. B., Mahmood, R. (2015). Knowledge management, entrepreneurial orientation and firm performance: the role of organizational culture. Asian Social Science, 11(23), 140-152.

Al-Nuiami, M., Idris, W. M. S., Al-Ferokh, F. A., Hussein, M. (2014). An empirical study of the moderator effect of entrepreneurial orientation on the relationship between environmental turbulence and innovation performance in five-star hotels in Jordan. International Journal of Business Administration, 5(2), 111-125.

Aloulou, W., Fayolle. A. (2005). A conceptual approach of entrepreneurial orientation within small business. Journal of Enterprising Culture, $13(1), 24-45$.

Amodu, A. A., Ama, A. (2016). Social networks and entrepreneurship orientation among students in Nigerian universities: a study of social network size and risk disposition. Business and Management Research, 5(2), 1-11. http://bmr.sciedupress.com.

Amolo, J., Migiro, S. O. (2014). Entrepreneurship complexity: salient features of entrepreneurship. African Journal of Business Management, 8(19), 832-841. http://doi.org/10.5897/AJBM2014.7442.

Arham, A. F. (2014). The relationship between leadership behaviour, entrepreneurial orientation and organizational performance in Malaysian small and medium enterprises (Doctoral Thesis). RMIT University. Melbourne, Australia. http://researchbank.rmit.edu.au/view/rmit:160765.

Avlonitis, G. J., Salavou, H. E. (2007). Entrepreneurial orientation of SMEs, product innovativeness, and performance. Journal of Business Research, 60(5), 566-575.

Awang, A., Khalid, S. A., Yusof, A. A., Kassim, K. M., Ismail, M., Zain, R. S., Madar, A. R. S. (2009). Entrepreneurial orientation and performance relations of Malaysian bumiputera SMEs: The Impact of Some Perceived Environmental Factors. International Journal of Business and Management, 4(9), 84-96.

Azevedo, R. (2008). The role of self-regulation in learning about science with hypermedia. In D. Robinson \& G. Schraw (Eds.), Recent innovations in educational technology that facilitate student learning. Charlotte, NC: Information Age Publishing.

Baba, R., Elumalai, S. (2011). Entrepreneurial orientation of SMEs in Labuan and its effects on performance. (Working Paper). Faculty of Economics and Business. University of Malaysia

Baum, J., Locke, E., Smith, K. (2001). A multidimensional model of venture growth. Academy of Management Journal, 44(2), 292-303.

Belgacem, B. (2015). Entrepreneurial orientation and firms' performance: the case of Tunisian companies. International Journal of Economics, Commerce and Management, 3(3), 1-15.

Beliaeva, T. (2014). Antecedents and performance outcomes of entrepreneurial orientation: a comparative cross country study (Master's Thesis). Saint-Petersburg Lappeenranta. University St. Petursberg, Russia.

Bigliardi, B. (2013). The effect of innovation on financial performance: a research study involving SMEs. Innovation. Management, Policy \& Practice, 15(2), 245-256. http://doi.org/10.5172/impp.2013.15.2.245. 
Böcskei, E., Fekete, H. (2012). Business performance measurement in the light of recent decades. The role of performance management, 3(1).1-5.

Boohene, R., Marfo-Yiadom, E., Yeboah, M. A. (2012). An empirical analysis of the effect of entrepreneurial orientation on firm performance of auto artisans in the Cape Coast Metropolis. Developing Country Studies, 2(9), 77-86.

Brown T. E., Davidsson, P., Wiklund, J. (2001). An operationalization of Stevenson's conceptualization of entrepreneurship as opportunitybased firm behavior. Strategic Management Journal, 22(10), 953 - 968.

Buckley, P., Park, B. (2014). Realized absorptive capacity, technology acquisition and performance in international collaborative formations: an empirical examination in the Korean context. Asia Pacific Business Review 20(1) 109-135.

Callaghan, C., Venter, R. (2011). An investigation of the entrepreneurial orientation, context and entrepreneurial performance of inner-city Johannesburg street traders. South African Business Review, 15(1), 28-48.

Carland Jr., J. W., Carland, J. A. C., Carland III, J. W. T. (2015). Self-actualization: the zenith of entrepreneurship. Journal of Small Business Strategy, 6(1), 53-66.

Cope, J. (2011). Entrepreneurial learning from failure: an interpretative phenomenological analysis. Journal of Business Venturing, 26(6), 604-623.

Coulthard, M. (2007). The role of entrepreneurial orientation on firm performance and the potential influence of relational dynamism. Journal of Global Business and Technology 3(1), 29-39.

Covin, J. G., Slevin, D. P. (2001). A conceptual model of entrepreneurship as firm behavior. Entrepreneurship Theory and practice, 16(1), 725.https://doi.org/10.1177/104225879101600102

Dahlander, L., Gann, D. M. (2010). How open is innovation? Research Policy, 39(6), 699-709.

Duru, I. U., Ehidiamhen, P. O., Chijioke, A. N. J. (2018). Role of entrepreneurial orientation in the performance of small and medium enterprises: evidence from capital territory, Abija, Nigeria. Asian Journal of Economics, Business and Accounting, 6(1), 1-21. DOI:10.9734/AJEBA/2018/39748

Ejdys, J. (2016). Entrepreneurial orientation vs. innovativeness of small \& medium size enterprises. Journal of Engineering, Project, Production Management, 6(1), 13-24

Engström, P., McKelvie, A. (2016). Financial literacy and firm performance in informal economy firms in Ecuador. Frontiers of Entrepreneurship Research, 36(16), Article 8. https://digitalknowledge.babson.edu/fer/vol36/iss16/8.

Ernest, K., Matthew, S. K., Samuel, A. K. (2015). Towards entrepreneurial learning competencies: the perspective of built environment students. Higher Education Studies, 5(1), 20-30.

Fairoz, F. M. (2010). Entrepreneurial orientation and business performance of small and medium scale enterprises of Hambanthota district Sri Lanka. Asian Social Science, 6(3), 34-46.

Fani, A. (2015). The relationship between knowledge management and organizational learning within middle and senior managers of Iranian public organization. Information and knowledge Management, 5(6), 102-213.

Frank, H., Kessler, A., Fink, M. (2010). Entrepreneurial orientation and business performance: a replication study. Schmalenbach Business Review, 62(2), 175-199.

Friedman, B. A., Aziz, N., Keles, I., Sayfullin, S. (2012). Predictors of students' desire to be an entrepreneur: Kyrgystan, Georgia and the United States. Eurasian Journal of Business and Economics, 5(9), 129 - 140.

Gamage, B. N. (2014). Entrepreneurship orientation, business performance appraisal of small and medium scale enterprises: reference to Hambanthota district, Sri Lanka. International Journal of Marketing, Financial Services and Management Research, 03(12), 174-185.

Gathungu, J. M., Aiko D. M., Machuki V. N. (2014). Entrepreneurial orientation, networking, external environment, and firm performance: a critical literature review. European Scientific Journal, 10(7), 335-357.

Gautam, P. R. (2016). Entrepreneurial Orientation and business performance of handicraft industry: a study of Nepalese handicraft enterprises. International Journal of Small Business and Entrepreneurship Research, 4(2), 48-63.

Gavrea, C., Ilies, L., Stegerean, R. (2011). Determinants of organizational performance: the case of Romania. Management \& Marketing Challenges for the Knowledge Society, 6(2), 285-300.

Ge, B., Hirsch, R. D., Dong, B., (2009). Networking, resource acquisition, and the performance of small and medium sized enterprises: an empirical study of three major cities in China. Managing Global Transitions, 7(3), 221-239.

George, G., Wood, D. R. Jr, Khan, R. (2001). Networking strategy of boards: implications for small and medium-sized enterprises. Entrepreneurship and Regional Development, 13(3), 269-285.

Gerba, Y. T., Viswanadham, P. (2016). Performance measurement of small scale enterprises: review of theoretical and empirical literature. International Journal of Applied Research, 2(3), 531-535 
Haider, S. H., Asad, M., Fatima, M., Abidin, R. Z. U. (2017). Microfinance and performance of micro and small enterprises; does training has an impact. Journal of Entrepreneurship and Business Innovation, 4(1).

Hamel, G. (2000). Leading the revolution. Boston, Masachusettes: Harvard Business School, Boston.

Hanafiah, M. H., Yousaf, U., Hashim, N. A., (2016). Entrepreneurs' intention to invest in current business: an empirical study of Malaysian SME entrepreneurs. Malaysian Journal of Society and Space, 12(2), 119-131.

Harvie, C. (2010). SMEs and regional production networks. In Integrating Small and Medium Enterprises into More Integrating East Asia. ERIA Research Report 2009 No.8, edited by V. T. Tranh, D. Narjoko, and S. Oum. Jakarta: Economic Research Institute for ASEAN and East Asia.

Hite, J. M., Hesterly, W. S. (2001). The evolution of firm networks: from emergence to early growth of the firm. Strategic Management Journal, 22, 275-286.

Hove, T. M. M., Goliath, J. E. (2016). The entrepreneurial orientation and business performance relationship: a study of young adult-owned small businesses. 28th Annual Conference of the Southern African Institute of Management Scientists, South Africa. https://www.researchgate.net/publication/317259073.

Hudson, M. A., Smart, A., Bourne, M. (2001). Theory and practice in SME performance measurement systems. International Journal of Operations \& Production Management, 21(8), 1096-1115.

Hult, G. T. M., Hurley, R. F., Knight, G. A. (2004). Innovativeness: its antecedents and impact on business performance. Industrial Marketing Management, 33(5), 429-38.

Hult, G. T. M., Snow, C. C., Kandemir, D. (2003). The role of entrepreneurship in building cultural competitiveness in different organizational types. Journal of Management, 29(3), 401-426.

Ilyas, M., Zahid, A., Rafiq, M. (2015). Impact of entrepreneurship education on intention and desire for venture creation. An Empirical Study of Entrepreneurs and Non Entrepreneur Graduates. Journal of Marketing and Consumer Research, 6, 57-65.

Jensen, J. I., ang Greve, A. (2002). Does the degree of redundancy in social networks influence the success of business start-ups? International Journal of Entrepreneurial Behavior \& Research 8(5), 254-267.

Judge, W., Douglas, T. J. (2013). Entrepreneurship as a leap of faith. Journal of management, spirituality \& religion, 10(1), 37-65.

Kaplan, R. S., Norton, D. P. (2010). Managing alliances with the balanced scorecard. Harvard Business Review, 88(1), 114-20.

Karyotakis, K. M., Moustakis, V. S. (2016). Organizational factors, organizational culture, job satisfaction and entrepreneurial orientation in public administration. The European Journal of Applied Economics, 13(1), 47-59.

Kasturiratne, D. (2012). International enterprise education in Sri Lanka: a blended approach. Education plus Training, 54(4), 306-318.

Kaunda, C. M. (2012). Entrepreneurial orientation, age of owner and small business performance in Johannesburg (Unpublished research report). Faculty of Commerce, Law and Management, University of the Witwatersrand.

Kemelgor, B. H. (2002). A comparative analysis of corporate entrepreneurial orientation between selected firms in the Netherlands and the USA. Entrepreneurship \& Regional Development, 14(1), 67-87. DOI: 10.1080/08985620110087023

Kraus, S., Burtscher, J., Vallaster, C., Angerer, M. (2018). Sustainable Entrepreneurship orientation: a reflection on status-quo research on factors facilitating responsible managerial practices. Sustainable, 10(2), 444- 465.https://doi.org/10.3390/su10020444.

Kraus, S., Rigtering, J. P. C., Hughes, M., Hosman, V. (2012). Entrepreneurial orientation and the business performance of SMEs: a quantitative study from the Netherlands. Review of Managerial Science, March 6,(2), 161-182.

Kreiser, P., Marino, L., Weaver, M. K. (2002). Correlates of entrepreneurship: the impact of national culture on risk-taking and proactiveness in SMEs. USASBE Annual National Con ference, 0225(205), 1-19. Retrieved from http://usasbe.org/knowledge/proceedings /proceedingResults.asp?keyword=kreiser\&proceedingyear=ALL\&b=\nhttp://usasbe.org/knowledge/proceedings/2002proceedings.asp.

Kropp, F., Zolin, R. (2005). Technological entrepreneurship and small business innovation research programs. Academy of Marketing Sciences Review,2005(07). www.amsreview.org/articles/kropp07-2005.pdf.

Kumara, P. A. P. S. (2012). Undergraduates' intention towards entrepreneurship: empirical evidence from Sri Lanka. Enterprising Culture, 20(1), 105-118. Retrieved from https://doi.org/10.1142/s0218495812500057

Kurtulmuşa, B. E., Warner, B. (2015). Entrepreneurial orientation and perceived financial performance. Does environment always moderate EO performance relation. Proceida-Social and Behavioural Sciences, 20(October 2015), 739-748. https://doi.org/10.1016/j.sbspro.2015.10.151

Lackeus, M. (2018). What is value? A framework for analyzing and facilitating entrepreneurial value. Uniped, 41, 10-28. DOI: 10.18261/issn.1893-8981-2018-01-02.

Laukkanen, T., Nagy, G., Hirvonen, S., Reijonen, H., Pasanen, M. (2013). The effect of strategic orientations on business performance in SMEs: a multi group analysis comparing Hungary and Finland. International Marketing Review, 30(6), 510-535. 
Lee, C., Lee, K., Pennings, J. M. (2001). Internal capabilities, external networks, and performance: a study on technology based ventures. Strategic Management Journal, 22(67), 615640.

Lumpkin, G. T., Dess, G. G. (2001). Linking two dimensions of entrepreneurial orientation to firm performance: the moderating role of environment and industry life cycle. Journal of Business Venturing, 16(5), 429-451. http://doi.org/10.1016/S0883-9026(00)00048-3.

Lumpkin, G. T., Dess, G. G. (2006). The effect of simplicity on the strategy-performance relationship: a note. Journal of Management Studies, 43(7), 1583-1604.

Lusthaus, C., M. H. Anderson, A. G., Carden, F., Montalvan, G. P. (2014). Organizational assessment: a framework for improving performance. Ottawa/Washington DC: International Development Research Centre and Inter-American Development Bank.

Madsen, E. L. (2007). The significance of sustained entrepreneurial orientation on performance of firms: a longitudinal analysis. Entrepreneurship and Regional Development, 19(2), 185-204.

Mahmood, R., Hanafi, N. (2013). Entrepreneurial orientation and business performance of women-owned small and medium enterprises in Malaysia: competitive advantage as a mediator International. Journal in Business and Social Sciences, 4(1), 82-90.

Maldonado-Guzmán G., Castro, S. Y. P. (2016). Entrepreneurial orientation level in Mexican SMEs. Journal of Management and Sustainability, 6(2), 89-96.

Mazzarol, T., Volery, T., Doss, N., Thein, V. (1999). Factors influencing small business start-ups. International Journal of Entrepreneurial Behavior and Research, 5(2), 48-63.

McMullen, J. S., Dimov, D. (2013). Time and the entrepreneurial journey: the problems and promise of studying entrepreneurship as a process. Journal of Management Studies, 50(8), 481-1512.

Memon, A. A., Ting, H., Ramayah, T., Chuah, F., Cheah, J. (2017). A review of methodological misconceptions and guidelines related to the application of structural equation modeling: A Malaysian scenario. Journal of applied structural equation modeling, 1(1), 1-13.

Miller, D. (2011). Miller (1983). revisited: A reflection on EO research and some suggestions for the future. Entrepreneurship Theory \& Practice, 35(5), 873-894.

Minniti, M., Bygrave, W. (2001). A dynamic model of entrepreneurial learning. Entrepreneurship Theory and Practice, 25(3), 5-16.

Moreno, A. M., Casillas, J. C. (2008). Entrepreneurial orientation and growth of SMEs: a causal model. Entrepreneurship Theory and Practice, 32, 507-528. doi:10.1111/j.1540-6520.2008.00238.x

Morris, M. H., Kuratko, D. F., Covin, J. G. (2008). Corporate entrepreneurship \& innovation. Thomson/South-Western Publishers, Mason, Ohio.

Mu, J., Di Benedetto, C. A. (2012). Networking capability and new product development. IEEE Transactions on Engineering Management, 59(1), 4-19.

Mudalige, D., Ismail, N. A., Malek, M. A. (2016). Exploratory study on relationship between entrepreneur characteristics and dynamic capabilities in export SMEs. Paradigm, 20(2), 113-130. https://doi.org/10.1177/0971890716672934.

Mulatu, F. (2014). Networking and business performance of medium sized enterprises in Addis Ababa. Addis Ababa University.

Nath, P. (2013). The impact of e-commerce in modernisation of traditional enterprises with special reference to the entrepreneurship development in BTAD of Assam. Global Research Methology Journal, 2(Feb-Mar-Apr), 1-9.

Ofem, B., (2014). Entrepreneurial orientation, collaborative networks and non profit performance. (PhD Dissertation). College of business and Economics, University of Kentucky, Lexington, Kentucky, USA.

Omisakin, O. M., Nakhid, C., Littrell, R., Verbitsky, J. (2016). Entrepreneurial orientation among migrants and small and medium enterprises. Journal of Business Administration Research, 5(1), p7. http://doi.org/10.5430/jbar.v5n1p7.

Palalic, R., Busatlic, S. (2015). Exploratory research on relationship between entrepreneurial orientation dimensions and business performance and growth of fast and slow growing small and medium enterprises in Bosnia and Herzegovina. International Journal of Business and Management, 10(2), 15-30. http://doi.org/10.5539/ijbm.v10n2p15.

Piirala, P. (2012). The impact of entrepreneurial orientation on firm performance: a comparative study of Finnish and German SMEs SME Business Management. (Master's thesis). Aalto University School of Business, Finland.

Poon, M. (2013). Statistically discriminating without discrimination, centre for the analysis of risk and regulation. London School of Economics. Industry and Innovation, 14(1), 95-119.

Priyanath, H. M. S., Premaratne, S. P. (2014). Dilemma of SME development programs in Sri Lanka,: a review in the lens of transaction cost economics. Sabaragamuwa University Journal, 13(2), $59-81$.

Quinlan, C. (2011). Business research methods. Cengage Learning: Stamford, CT.

Radipere, S. (2015). Entrepreneurial orientation: a case of Gauteng Province, South Africa. Foundations of Management, 7(1), $169-184$. DOI: https://doi.org/10.1515/fman-2015-003. 
Rae, D. (2004). Entrepreneurial learning: a practical model from the creative industries. Education plus Training, 46(8/9), 492-500.

Rae, D., Ruth, W. N. (2013). How does enterprise and entrepreneurship education influence postgraduate students' career intentions in the New Era economy?. Education + Training, 55(8/9), 926-948. https://doi.org/10.1108/ET-07-2013-0095.

Raimond, E. (2016). What difference does good monitoring \& evaluation make to world bank project performance? Washington DC: Independent Evaluation Group. World Bank. https://openknowledge.worldbank.org/handle/10986/24644 License: CC BY 3.0 IGO.

Ranasinghe, S. (2008). Factors contributing to the success of women entrepreneurs in Sri Lanka. 1st research conference organized by National Centre for Advanced Studies.

Rasli, A. Md., Khan, S. R., Malekifar, S., Jabeen S. (2013). Factors affecting entrepreneurial intention among graduate students of university technology Malaysia. International Journal of Business and Social Science, 4(2), 182-188.

Rauch, A., Wiklund, J., Lumpkin, G., Frese, M. (2009). Entrepreneurial orientation and business performance: an assessment of past research and suggestions for the future. Entrepreneurship Theory and Practice 33(3), 761-787.

Rosli, M. M., Sidek, S. (2013). The impact of innovation on the performance of small and medium manufacturing enterprises: evidence from Malaysia. Journal of Innovation in Small and Medium Enterprise, 2013(2013), 1-16. DOI: 10.5171/2013.885666.

Rua, O. M. M. M. de L., França, A. M. S. S. (2016). Influence of entrepreneurial orientation and absorptive capacities in export performance. Tourism and Management Studies, 12(1), 196-202. DOI: 10.18089/tms.2016.12121.

Runyan, R., Droge, C., Swinney, J. (2008). Entrepreneurial orientation versus small business orientation: what are their relationships to firm performance? Journal of Small Business Management, 46(4), 567-588.

Rutten, R., Boekema, F. (2007). The learning region: foundations, state of the art, future. Chapter 1 in The Learning Region, (edited by). Cheltenham: Edward Elgar.Publishing.

Salehia, M., Ghorbanib, B. (2011). A study of using financial and non-financial criteria in evaluating performance: some evidence of Iran. Serbian Journal of Management, 6(1), 97-108.

Schepers, J., Voordeckers, W., Steijvers, T., Laveren, E. (2014). The entrepreneurial orientation-performance relationship in private family firms: the moderating role of socioemotional wealth. Small Business Economics, 43(1), 39-55.

Shane, S., Venkataraman, S. (2000). The promise of entrepreneurship as a field of research. Academy of Management Review, 25, 217-226.

Soininen, J. (2013) Entrepreneurial orientation in small and medium-sized enterprises during economic crisis (PhD Thesis). School of Business, Lappeenranta University of Technology, Finland.

Sok, P., Snell, L., Lee, W. J., Sok, K. M. (2017). Linking entrepreneurial orientation and small service firm performance through marketing resources and marketing capability. Journal of Service Theory and Practice, 27(1), 231-249. https://doi.org/10.1108/JSTP-01-2016-0001.

Sriprasert, P. (2013). The effect of entrepreneurial orientation on the success of community enterprise: a study of Nakhonsithammarat, Thailand. International Proceedings of Economics, 59(33), 158- 162

Stam, W., Elfring, T. (2008). Entrepreneurial orientation and new venture performance: the moderating role of intra- and extra industry social capital. Academy of Management Journal 51(1), 97-111.

Su, Z., Xie, E., Wang, D. (2013). Entrepreneurial orientation, managerial networking and new venture performance in China. Journal of Small Business Management, 53(1), 228 - 248. https://doi.org/10.1111/jsbm.12069.

Sunter, C. (2000). The entrepreneurs field book. Upper Saddle River, NJ: Prentice Hall.

Swierczek, F. W., Ha, T. T. (2003). Entrepreneurial orientation, uncertainty avoidance and firm performance. Entrepreneurship and Innovation, 46-58. Retrieved from https://doi.org/10.5367/000000003101299393.

Taatila, V., Down, S. (2012). Measuring entrepreneurial orientation of university students. Education + Training, 54(8), 744-760.doi: 10.1108/00400911211274864.

Tang, J., Tang, Z., Marino, L. D., Zhang, Y., Li, Q. (2008). Exploring an inverted u-shape relationship between entrepreneurial orientation and performance in Chinese ventures. Entrepreneurship Theory and Practice, 32(1), 219-239.

Van Doorn, S. V., Van Jansen, J. J. P., Van den Bosch, F. A. J. (2013). Entrepreneurial orientation and firm performance: drawing attention to the senior team. Journal of Product Innovation Management, 30(5), 821-836.

Vij, S., Bedi, H. S. (2012). Relationship between entrepreneurial orientation and business performance: a review of literature. The IUP Journal of Business Strategy, 9(3), 17-31.

Wales, W., Gupta, V. K., Mousa. F. (2011a). Empirical research on entrepreneurial orientation: an assessment and suggestions for future research. International Small Business Journal, 31(4):357-383,

Wang C. L. (2008). Entrepreneurial orientation, learning orientation, and firm performance. Entrepreneurship Theory and Practice, 32,(4), 635-657. DOI: 10.1111/j.1540-6520.2008.00246.x. 
Wang, Y, Poutziouris, P. (2010). Entrepreneurial risk taking: empirical evidence from UK family firms. International Journal of Entrepreneurial Behaviour and Research, 16(5), 370-388.

Wedathanthrige, H. (2014). Personal competencies for innovation: a case study of small and medium enterprises of coir industry in the north western province of Sri Lanka. Ruhuna Journal of Management and Finance, 1(1), 15-24.

Weerakoon, C. (2014). Organizational Determinants of Entrepreneurial Orientation: (With Reference to Small Scale ITBPO Firms in Sri Lanka). International Journal of Science and Research, 3(10):1240-1247.

Weimei, Z., Feng-e, T. (2012). Analysis of performance management in small and medium enterprises. 2nd International Conference on Mechanical, Industrial, and Manufacturing Engineering IERI.Procedia, 1, 8-12.

Wickramaratne, A, Kiminami, A., Yagi, H. (2014). Entrepreneurial competencies and entrepreneurial orientation of tea manufacturing firms in Sri Lanka. Asian Social Science, 10(18), 50-62.

Wijesekara, W. A., Kumara, P. A., Gunawardana, T. S. (2014). The impact of market orientation and entrepreneurial orientation on performance: a study on small and medium scale garment manufacturers in Sri Lanka. Proceedings of the 3rd International Conference on Management and Economics. Matara, Sri Lanka, 26-27 February 2014. Matara, Sri Lanka: Faculty of Management and Finance, University of Ruhuna, Sri Lanka.

Wiklund, J., Shepherd, D. (2005). Entrepreneurial orientation and small business performance: a configurationally approach. Journal of Business Venturing, 20(1), 71-91.

Yang, C. W. (2008). The relationships among leadership styles, entrepreneurial orientation and business performance. Managing Global Transitions, 6(3), 257-275

Zahra, S. A., Garvis, D. M. (2000). International corporate entrepreneurship and firm performance: the moderating effect of international environmental hostility. Journal of Business Venturing, 15(5-6), 469-492.di b

Zainol, F. A., Ayadurai, S. (2011). Entrepreneurial orientation and firm performance: the role of personality traits in Malay family firms in Malaysia. International Journal of Business and Social Science, 2(1), 59- 72.

Zhang, X., Zhao, J., LeCun, Y. (2015). Character-level convolutional networks for text classification. Advances of Neural Information Processing Systems, 28, $649-657$.

Zimmerman, M. A., Chu, H. M. (2013). Motivation, success and problems of entrepreneurs in Venezuela. Journal of Management Policy and Practice, 14(2), 76-90.

Zsido, K. E., Fenyves, V. (2015). Application of traditional and new approach methods in business performance measurement. CrossCultural Management Journal, 17(1), 51-57. 